(A302) Le Feu Dans Un Hôpital, De L'incident À La Catastrophe

F. Lévy

Service De Santé et De Secours Médical, Colmar, France

Le feu dans un hôpital ou une maison de retraite présente des caractéristiques de risque particulier. A propos de la combustion d'un mètre cube de couches culottes pour adulte au Centre hospitalier de Pfastatt dans le Sud de l'Alsace, ces risques particuliers seront montrés. Ce feu globalement insignifiant en terme de quantité de comburant a cependant entraîné quatre morts par inhalation des fumées et plusieurs intoxiqués ainsi que l'évacuation de tout une aile de l'hôpital avec hospitalisation d'une cinquantaine de patients dans d'autres structures de soins sans compter les pertes matérielles et financières liées à la réparation des dégats. Les opérations d'extinction, de triage et d'évacuation des patients se sont déroulées simultanément nécessitant la mise en oeuvre du plan rouge pour nombreuses victimes, une opération de mise en sécurité des patients hospitalisés et l'évacuation vers les structures adaptées avec une coopération et une coordination entre les diférentes structures de secours intervenantes. Les investigations médicolégales secondaires ont permis de montrer chez tous les patients décédés une forte intoxication aux cyanures liée à la nature du comburant et responsables du décès rapide. Ceci pose le problème du stockage de ce type de produit et surtout de la disponibilité d'Hydroxocobalamine, antidote spécifique, en quantité suffisante pour des établissements à risque possédant beaucoup de produits synthétiques. Enfin il convient de signaler que le personnel hospitlier doit être entrainé à avoir les bonnes réactions devant un développement de fumées car c'est en premier de leurs attitudes que dépend la vie des patient en particulier s'ils sont alités.

Prehosp Disaster Med 2011;26(Suppl. 1):s85

doi:10.1017/S1049023X1100286X

\section{(A303) Aspects Actuels Du Triage, Pour Une Synthèse} H. Julien

Ile De France, Paris, France

Le triage des victimes en nombre s'impose aujourd'hui comme une nécessité opérationnelle. Les deux actions complémentaires qui le caractérisent: catégorisation des blessés et dispensation des soins d'urgence sont universellement admis. Il a plusieurs buts: repérer les blessés les plus graves pour leur donner les soins dans les meilleurs délais, les regrouper par niveaux de soins afin d'y consacrer les sauveteurs-soignants correspondants, mieux gérer les flux de blessés et dans le même temps administrer les premiers soins. Le triage de victimes de catastrophes civiles, a longtemps été considéré en France comme un acte médical, réalisé par les seuls médecins placés à l'entrée du Poste Médical Avancé, où sont dispensés les soins d'urgence et la mise en condition des victimes, nécessaires à leur évacuation vers les structures d'accueil et de soins. Aujourd'hui, notamment sous l'influence anglo-saxone un triage préalable est effectué par les sauveteurs sur le terrain, afin de catégoriser les victimes du ramassage avant leur transfert sur le PMA: ce pré-triage, premier triage, est connu sous le nom de "Simple Triage And Rapid Treatment». Une synthèse est nécessaire afin notamment que dans des conditions d'intervention internationalisées, les personnels de sauvetage et de soins d'urgence disposent d'une méthode à application universelle. Cela est rendu possible en soulignant l'aspect dynamique du triage qui se réalise et se complète d'étape en étape: sur le terrain au moment du ramassage par les sauveteurs, médicalisés ou non, au niveau du PMA ou du module de chirurgie vitale où seront pratiquées " damage control ", réanimation et mise en condition d'évacuation, à la structure d'accueil ou sera réalisé le triage de vérification. Les critères retenus pour le triage des enfants, des brûlés, des victimes irradiées ou contaminées chimiques, les blessés psychiques viennent compléter les critères fonctionnels et lésionnels classiquement retenus.

Prehosp Disaster Med 2011;26(Suppl. 1):s85 doi:10.1017/S1049023X11002871

(A304) Catastrophe Biologique Dans La Ville De Rio L.T. Silveira, ${ }^{1}$ L.M. Plotkowski, ${ }^{2}$ I.A.G. De Souza, ${ }^{3}$ D.P. Borghi, ${ }^{1}$ H. Julien ${ }^{4}$

1. GSE, Rio De Janeiro, Brazil

2. Prehostpital and Disaster Medicine, Rio De Janeiro, Brazil

3. Assessoria, Rio De Janeiro, Brazil

4. Ile De France, Paris, France

Catastrophe Biologique dans la Ville de Rio. Silveira L, Plotkowski LM, Arouche I, Borghi D, Julien H. Sécretariat d'Etat de ls Santé et Defense Civile.. Au début de l'été de 2007 la ville Rio a subi une catastrophe responsable de 232 morts (42\% d'enfants ) et 150.00 malades. En quelques semaines, l'épidémie de dengue a bloqué toute la structure de soins de Rio. Les hôpitau pourtant dotés de plans blancs, n'ont pu faire face a l'afflux massif de patients. La gravité était due au choc hypovolémique par perte de plasma, plus quaux hémorragies. La diffusion alarmiste de la presse a augmenté les réactions de panique populaire. En février 2008, chaque heure des centaines de nouveaux cas ont été enregistrés. Les autorités réunies (Secrétariat d" État de la Santé et Sécurité Civile, Le Service de santé du Sapeur Pompier, de 1 Ármée de Terre, de la Marine et de l' Armée de L'Air) ont décidé d'installer 12 PMA (Hôpitaux de Campagne) pour trier les malades et les hydrater sur place. Chaque "Tente d'Hydratation” a été équipée d'un laboratoire d'analyse ( hémogramme et plaquettes) de 30 lits pour l'hydratation en perfusion, deux lits de réanimation et une ambulance, pour le transfert vers 1'hôpital de référence. Près de 1000 professionnels de santé y ont travaillé. Dans le premier mois, 49700 consultation on été assurées dans les PMA. Les patients étaient tous triés et $10 \%$ ont eu besoin d'une hydratation par perfusion pendant 12 heures en moyenne. Seulement $2 \%$ des malades ont été hospitalisés. Le diagnostique précoce et l'hydratation rapide a permis aux PMA de renvoyer les malades chez eux, de réduire efficacement l'afflux hospitalier et la mortalité par dengue. Les PMAs ont été démontés progressivement à mesure du contrôle de l'épidémie, jusqu'a 2 mois plus tard.

Prehosp Disaster Med 2011;26(Suppl. 1):s85

doi:10.1017/S1049023X11002883

\section{(A305) Un Outil Pour La Maîtrise De L'accident Collectif \\ J. Pitteloud}

Anesthesiology, Sion, Switzerland

Le tableau croisé, un outil pour la maitrise de l'accident collectif Dr J.-C. Pitteloud, Sion (Suisse) Lorsqu'on est confronté Á un 
accident Á plusieurs victimes, il est souvent difficile de garder en tête Á la fois les victimes et les moyens dont vous disposez. Le tableau croisé est un formulaire qui permet de diriger et de documenter efficacement une intervention sur un accident Á plusieurs victimes. Le principe du tableau croisé est que vous allez regrouper les informations sur les victimes, comme leur numéro et leur catégorie de triage sur les lignes horizontales de votre tableau (l'axe des X). Les information sur les vecteurs (heure d'appel, heure d'arrivée) seront notées sur les colonnes ( l'axe des y). L'heure de prise en charge de chaque victime par une unité est notée Á l'intersection correspondante. L'heure d'Évacuation vers l'hôpital est notée au bout de chaque colonne et de chaque ligne. Ce formulaire permet de garder une vue d'ensemble des opérations de secours Á victime ainsi que de documenter l'action de chaque Équipe et le devenir de chaque patient. Il est utilisable dû l'arrivée de la première Équipe sur place, puisqu'il suffit d'un stylo et d'une feuille de papier pour le réaliser. Dans notre expérience, une feuille de format A4 européen permet de gérer une intervention pour une dizaine de victime, une feuille de format A5 jusqu'Á une trentaine.

Prehosp Disaster Med 2011;26(Suppl. 1):s85-s86

doi:10.1017/S1049023X11002895

(A306) Community Resilience and the Christchurch Earthquake: Best Laid Plans or Practise Made Perfect? A.R.G. Humphrey, J. Mitchell, S.K. Mcbride

Medical Officer of Health, Canterbury, New Zealand

On February 22, 2011 at 12:51 pm an earthquake measuring 6.3 on the Richter scale struck the city of Christchurch, population 376,700 in the South Island of New Zealand. This followed a 7.3 magnitude earthquake in September 2010, but the shallowness $(5 \mathrm{~km})$ and proximity of the February earthquake to the central city, resulted in far more devastation, with Modified Mercalli scores reaching ten in some areas and upward ground acceleration exceeding $2.4 \mathrm{G}$. The application of the Coordinated Incident Management System (CIMS) routinely used by New Zealand Civil Defence agencies was swift, innovative and efficient, facilitating rapid deployment of local and international emergency teams and response resources. The effectiveness of this response was partially attributed to lessons learnt from the September earthquake which, with hindsight, was a practise for the more serious February event. The community response was equally remarkable, with standard approaches to measuring preparedness and resilience suggesting that community resilience in Canterbury was high. A number of initiatives by the NewZealand Ministry of Civil Defence and Emergency Management may have fostered some of this resilience,particularly communitybased resilience-building projects initiated by the Regional Emergency Management Office on 2009 and 2010, supported by the Ministry of Civil Defence and Emergency Management. In addition, website education resources and media promotion ("Get Ready Get Thru") and a travelling exhibition called "The Pandemic Roadshow" had been particularly well received and remembered by Canterbury residents. However, two key events provided an impetus for the Canterbury community to burnish its resilience. First, the Swine flu (AH1N1) pandemic in 2009 resulted in a greater awareness of public health in emergencies along with a doubling of neighbourhood support groups.
Secondly, the September 2010 earthquake resulted in the establishment of the student army of volunteers and improvement of public information management. This presentation will describe the markers of community resilience following the Christchurch earthquake and discuss how such resilience can be fostered in communities where emergency preparedness is not recognised as a priority.

Prehosp Disaster Med 2011;26(Suppl. 1):s86

doi:10.1017/S1049023X11002901

(A307) Disaster Task Force's Management Support at Emergency Response Phase in the Merapi Eruption November 2010

\section{H. Wartatmo}

Centre of Health Service Management, Faculty of Medicine, Yogyakarta, Indonesia

Background: Merapi, the most active volcano in the world, erupted on the 26th October 2010 at 17.02, and followed by several eruptions. The biggest eruption was on the 5 th of November 2010. Damages were catastrophic: 386 people killed, and more than $\$ 400$ million lost. A wide area of fertile lands and settlements were destroyed which resulted in more than 200.000 refugees. This disaster had impact to 2 provinces and 6 districts. At the emergency phase, a special task force was established by central government of Indonesia. This paper aims to evaluate the task force and the role of its management support during the acute phase in the disaster.

Method: an input and process evaluation of task force work was implemented.

Results: The input evaluation shows that the task force members for emergency response came from central, provincial, district government employees, universities and non government organisation members. The financial sources are from public and private funding. The activities process of task force in forms of health response command system, temporary information system, communication and telecommunication system, supporting the volunteer groups, managing the refugees camps, implementing surveillance system, and backed up the local district health officers. There were problems of programs coordination and channelling the budget from national treasury due to the multiple eruptions. Most of these problems were solved by a management support team for the task force.

Conclusion: The multiple strikes of Merapi eruption needs better human resources management and financial support. During Merapi eruption, it is proved that a management support for emergency response task force is important. This management support allowed better control and coordination of available resources.

Prehosp Disaster Med 2011;26(Suppl. 1):s86

doi:10.1017/S1049023X11002913

\section{(A308) Come Hell and Cold, High Water...}

\section{A.J. Mclean}

Fargo, United States of America

It is extremely rare in disaster mental health annals to have consistent psychosocial interventions pre-disaster. For the third year in a row, the Red River Valley of the United States and Canada 